\title{
Hepatic and cardiac necrosis in a patient with prostatic carcinoma given $\epsilon$-aminocaproic acid
}

\author{
F. NOUR-ELDIN AND T. F. DRAISEY \\ From the Department of Pathology, Southmead Hospital, Bristol
}

SYNOPSIS The pathological findings in a case of prostatic carcinoma with fibrinolysin, treated with $\epsilon$-aminocaproic acid, included hepatic and cardiac necrosis. The possibility is discussed that the latter lesions may be a complication of $\epsilon$-aminocaproic acid therapy or produced by the proteolytic action of the fibrinolysin.

Normal prostatic tissue appears to contain a fibrinolysin (Tagnon, Schulman, Whitmore, and Kravitz, 1952). Hypertrophy or carcinoma of the prostate is frequently complicated by the release into the blood of an excessive amount of this fibrinolytic agent or increased levels of plasminogen activator (Astrup, 1956; Sherry, Fletcher, and Alkjaersig, 1959) which may or may not cause a bleeding diathesis. We describe in this communication a patient with prostatic carcinoma in whom the pathological picture comprised in addition to fibrinolysin, lysis of factor $\mathbf{V}$ and necrosis of both liver parenchyma and heart muscle.

\section{CASE REPORT}

A 47-year-old painter, employed by a brewery, was seen by an orthopaedic surgeon at another hospital in August 1961 complaining of pain in the left buttock and leg. Clinical and radiological examination showed no abnormality. Having derived no benefit from a prescribed supporting belt for six weeks, he was treated by manipulation.

In November 1961 he was admitted to this hospital on account of weakness of the left leg and difficulty in micturition. Examination revealed loss of power in the left lower limb but no changes in the reflexes. There was slight hepatomegaly. A firm, tender prostate was felt and opacities suggesting secondary carcinoma of the spine and left femur were detected in radiographs. Laboratory tests showed serum acid phosphatase levels of 415 King-Armstrong units, alkaline phosphatase $\mathbf{4 0}$ units, and proteins $7 \cdot 2 \mathrm{~g}$. per $100 \mathrm{ml}$. Paper electrophoresis of serum showed normal bands. Injections of intravenous Honvan (stilboestrol diphosphate) caused severe pain in the perineum and left buttock. Treatment with stilboestrol, $5 \mathrm{mg}$. t.d.s., was begun on 9 November.

On 20 November the patient developed haematuria

Recieved for publication 3 May 1962. and a purpuric rash on the trunk and limbs. The haemoglobin was $63 \%(9.3 \mathrm{~g} . / 100 \mathrm{ml}$.) with 125,000 platelets per c.mm. On the following day bleeding from the gums and venepuncture sites occurred. After obtaining blood for testing the coagulation mechanism, $10 \mathrm{mg}$. vitamin $\mathrm{K}$ was given intramuscularly. The blood sample showed fibrinolysin and factor $V$ deficiency. Accordingly, the patient was given a transfusion of $2,160 \mathrm{ml}$. fresh acidcitrate-dextrose blood and oral $\epsilon$-aminocaproic acid, $2 \mathrm{~g}$. every six hours, to a total dose of $26 \mathrm{~g}$. After 48 hours bleeding was noticeably reduced and the haemoglobin level was $69 \%(10.2 \mathrm{~g} . / 100 \mathrm{ml}$. $)$. The general condition of the patient improved and the serum acid phosphatase level fell to 60 K.-A. units. However, the liver enlargement became more marked and the blood-clotting mechanism on 11 December showed no appreciable change. After coughing up blood-stained sputum, the patient suddenly became unconscious and died on 23 December.

During his stay in hospital, he also received tab. ferri glucon t.d.s. for 11 days, and, when necessary, omnopon, pethidine, and sodium amytal, none of which in therapeutic doses is known to have any serious toxic effect on the liver.

\section{NECROPSY AND HISTOLOGY}

At necropsy the body was that of a well-nourished man with a fading purpuric rash on the trunk. There was no evident jaundice. Death was due to haemorrhage into the substance of the right cerebral hemisphere bursting into the ventricular system and tracking into the subarachnoid space. The vessel from which bleeding originated could not be located. Recent haemorrhage was demonstrated histologically in the brain tissue. All other internal organs were free of haemorrhagic manifestations.

The slightly enlarged prostate was smooth and of an even white consistency without evidence of local invasion. Section (Fig. 1) showed a well-differentiated adenocarcinoma of the prostate. 
The liver was evenly enlarged and weighed $2,996 \mathrm{~g}$. The cut surface was pale and finely mottled throughout with no evidence of metastatic tumour. Histological examination showed that many of the liver cells were pale and vacuolated with nuclei showing karyorrhexis. These areas of necrosis (Fig. 2), mainly peripheral in distribution, were seen in all lobules. There was a scanty cellular exudate, composed of polymorphonuclear cells and macrophages, around the dead cells and in the portal areas. The latter showed no increase in fibrosis and the patent bile ducts were not proliferating.

The heart weighed $326 \mathrm{~g}$. and was anatomically normal. The coronary arteries showed no signs of occlusion or atheroma. Histologically, there were scattered small areas of necrosis in the myocardium, consisting of pale ghosts of muscle fibres with intact sarcolemmal nuclei (Fig. 3). There was also a scanty polymorphonuclear exudate.

There were deposits of metastatic tumour in the lumbar vertebrae and in the head of the right femur. On section these bones showed diffuse infiltration with small dense tumour cells and an osteoblastic reaction.

The kidneys were normal macroscopically and microscopically and the other organs showed no evident pathological lesions.

\section{BLOOD CLOTTING TESTS}

The tests used are shown in Table I.

Deficiency of factor $\mathrm{V}$ was demonstrated by observing the effect of serum, plasma, and $\mathrm{Al}(\mathrm{OH})_{3^{-}}$ treated plasma on the one-stage prothrombin time as well as by the influence of antihaemophilic globulin and factor $\mathrm{V}$ on the deficient thromboplastin generation.

Fibrinolysin was measured by comparing the fibrinolytic activity of undiluted and diluted $(1: 2$ to
$1: 8)$ patient's plasma and normal (control) reagent. Equal volumes of the plasma, human fibrinogen (200 mg./100 ml.), bovine thrombin (10 units $/ \mathrm{ml}$.), and $0.025 \mathrm{M} \mathrm{CaCl}_{2}$ were mixed and incubated at $37^{\circ} \mathrm{C}$. The tubes were observed at intervals of 30 minutes. The presence of abnormal lysis is usually apparent within four hours. In a normal plasma a good clot is still present in all tubes after 24 hours.

The results, summarized in Table I, showed a deficiency of factor $\mathrm{V}$ and a slight diminution in the platelet count. The fibrinogen concentration was very low. A high concentration of fibrinolysin was also present; complete lysis occurred in two hours in undiluted plasma and in nine and a half hours with a $1: 8$ dilution.

When normal citrated plasma was incubated at $37^{\circ} \mathrm{C}$. with the patient's plasma or serum a gradual and marked prolongation of the one-stage prothrombin time was noticed (Table II). This was corrected by the addition of $\mathrm{Al}(\mathrm{OH})_{3}$-treated plasma, indicating destruction of factor $\mathrm{V}$ by the patient's plasma and serum.

TABLE II

EFFECT OF PATIENT'S PLASMA AND SERUM ON PROTHROMBIN TIME OF NORMAL PLASMA

\begin{tabular}{rccc}
$\begin{array}{l}\text { Incubation } \\
\text { Period } \\
\text { (min.) }\end{array}$ & \multicolumn{3}{l}{ One-stage Prothrombin Time (sec.) } \\
\cline { 2 - 4 } & $\begin{array}{l}\text { Patient's } \\
\text { Plasma }\end{array}$ & $\begin{array}{l}\text { Patient's } \\
\text { Serum }\end{array}$ & $\begin{array}{l}\text { Buffered } \\
\text { Saline }\end{array}$ \\
\hline 0 & 15 & $14 !$ & $14 !$ \\
10 & 16 & 17 & 14 \\
30 & 18 & 20 & 13 \\
60 & 22 & 22.1 & 14 \\
120 & 28 & 27 & 14 \\
180 & 37 & 38 & 14 \\
240 & 39 & 38 & 15
\end{tabular}

${ }^{1}$ Buffered saline consisted of equal volumes of imidazole buffer $p \mathrm{H} 7 \cdot 3$ and $0.9 \% \mathrm{NaCl}$.

TABLE I

RESULTS OF BLOOD-CLOTTING TESTS

\begin{tabular}{|c|c|c|c|}
\hline Test & Patient & Normal & Remarks \\
\hline $\begin{array}{l}\text { Blood clotting time (min.) } \\
\text { Plasma clotting time (min.) } \\
\text { One-stage prothrombin time (sec.) } \\
\text { Mixed with } 10 \% \text { of: Normal plasma } \\
\qquad \begin{array}{l}\text { Al }(\mathrm{OH})_{3} \text {-treated normal plasma } \\
\text { Normal serum } \\
\text { Fibrinogen } 400 \mathrm{mg} . / 100 \mathrm{ml} .\end{array} \\
\text { Two-stage prothrombin estimation }(\%)\end{array}$ & $\begin{array}{l}9 \frac{1}{2} \\
6 \frac{1}{2} \\
37 \\
20 \\
20 \\
37 \\
35 \\
95\end{array}$ & $\begin{array}{l}4-7 \\
1 \frac{1}{2}-4 \\
11-12 \\
- \\
- \\
- \\
90-100\end{array}$ & Delay in reaching peak of curve \\
\hline $\begin{array}{l}\text { Thromboplastin generation test (substrate clotting time } \\
\text { Plasma } \\
\text { Serum } \\
\text { Platelets }\end{array}$ & $\begin{array}{l}25 \\
10 \\
10\end{array}$ & $\begin{array}{l}9-10 \\
9-10 \\
9-10\end{array}$ & Corrected with factor $\mathrm{V}$ but not with factor VIII \\
\hline $\begin{array}{l}\text { Platelet count }\left(10^{3} / \mathrm{c} . \mathrm{mm} .\right) \\
\text { Fibrinogen }(\mathrm{mg} . / 100 \mathrm{ml} .) \\
\text { Bleeding time }(\mathrm{min} .)\end{array}$ & $\begin{array}{r}125 \\
40 \\
16\end{array}$ & $\begin{array}{l}200-400 \\
200-400 \\
2-4\end{array}$ & \\
\hline
\end{tabular}

Bleeding time (min.) 


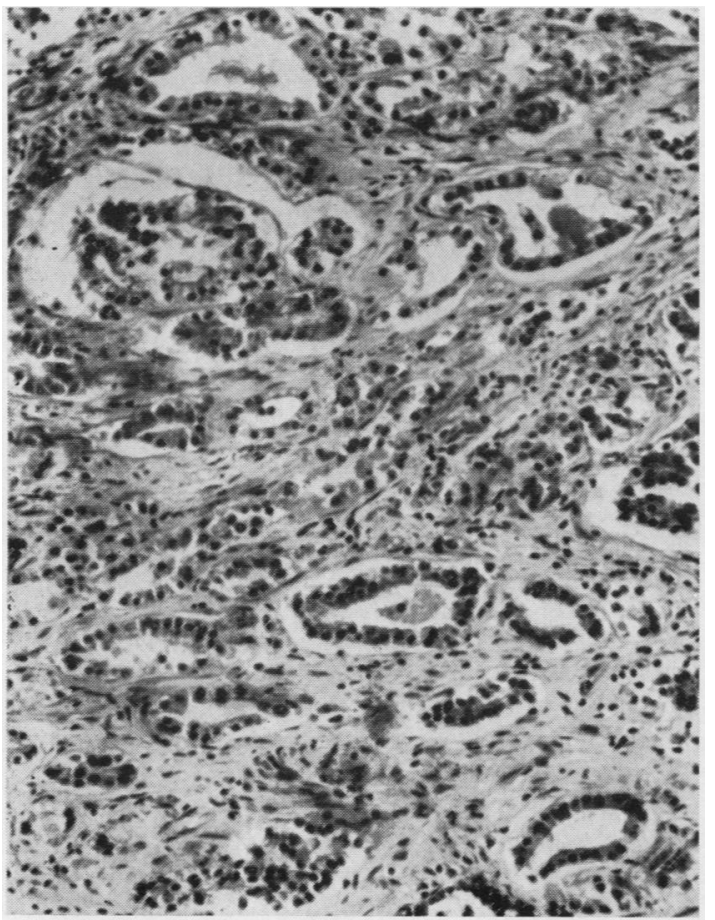

FIG. 1

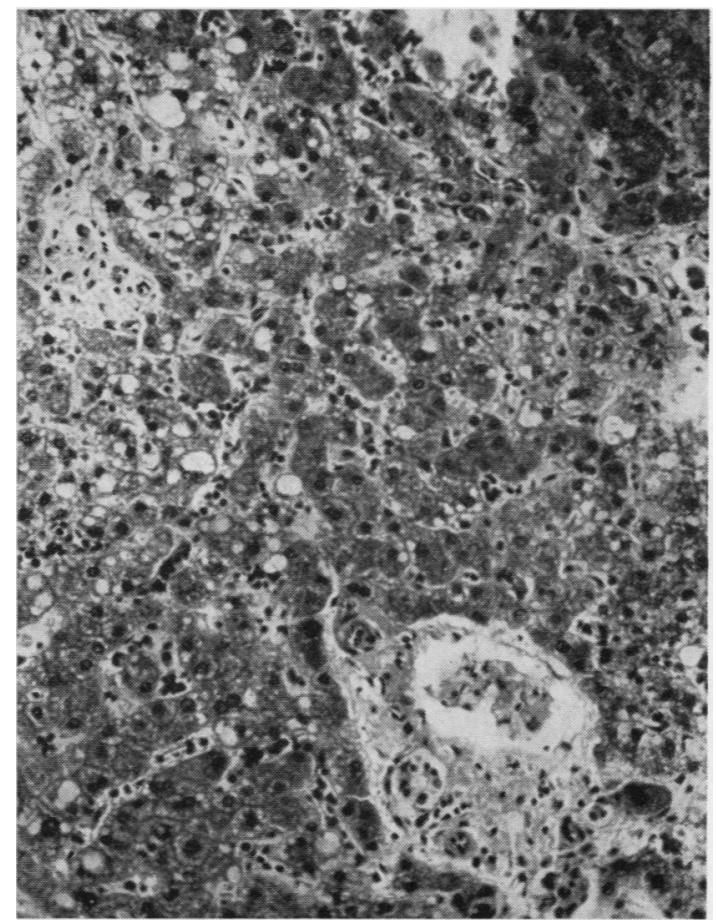

FIG. 2

FIG. 1. Prostate showing well-differentiated adenocarcinoma (haematoxylin and eosin $\times 100$ ).

FIG. 2. Liver showing vacuolation and necrosis of parenchymal cells with scanty inflammatory reaction (haematoxylin and eosin $\times 100$ ).

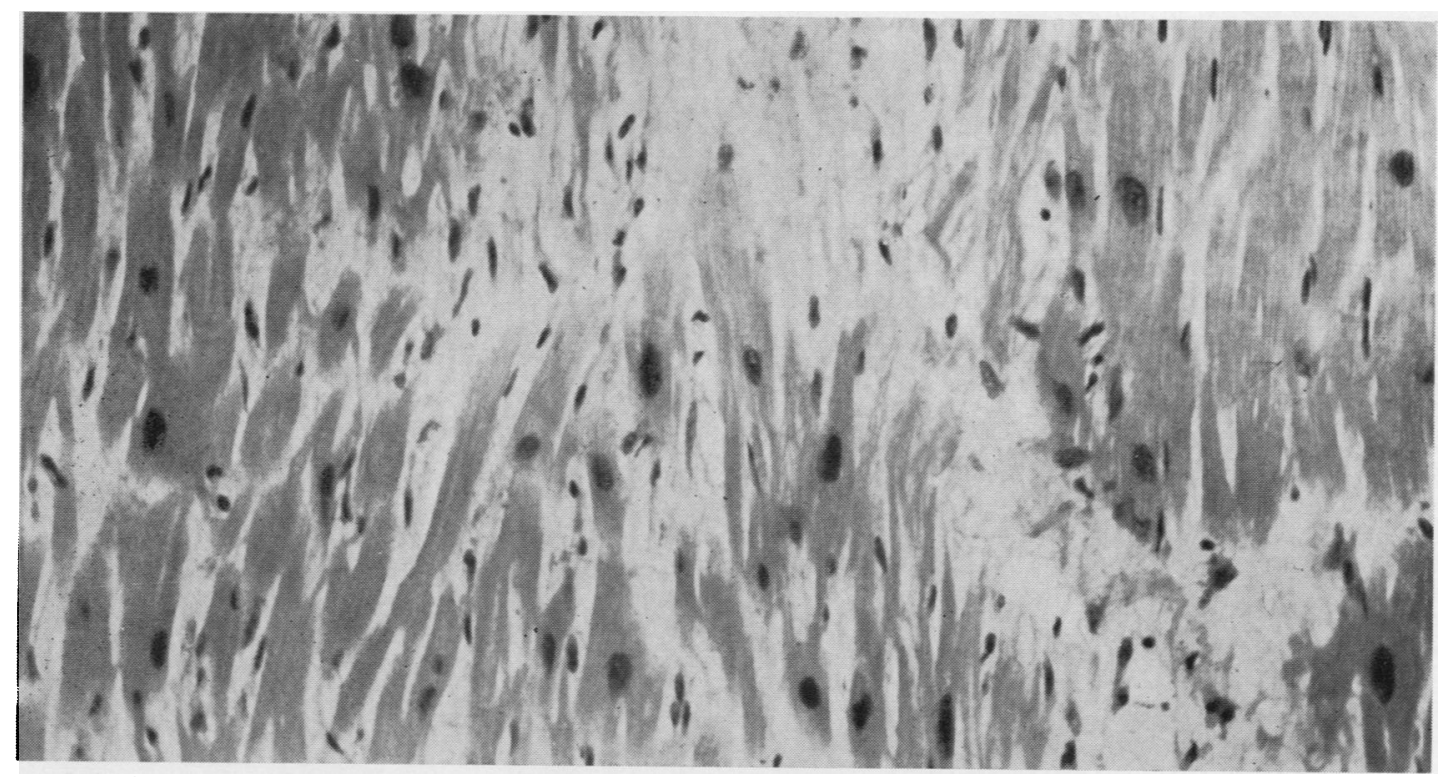

FIG. 3. Focal necrosis of myocardium (haematoxylin and eosin $\times 200$ ). 


\section{DISCUSSION}

The patient reported here presents some interesting features. Tagnon et al. (1952) thought that the fibrinolysin present in cases of prostatic carcinoma also proteolyzed one or several of the factors entering into the first phase of coagulation and this prolonged the one-stage prothrombin time. These authors, however, did not identify the factor(s) involved. In the present case factor $V$ was specifically lysed.

Extensive liver damage or advanced metastatic carcinoma may cause factor $\mathrm{V}$ deficiency (Owren, 1949; Stefanini, 1951; Cosgriff and Leifer, 1952) most probably by causing less factor $\mathrm{V}$ to be produced in the liver. In the present case we have no concrete evidence showing disturbance of the liver functions (the high serum alkaline phosphatase level could have been due to bone being infiltrated by the tumour) and no hepatic metastasis was seen. Nevertheless, the extensive necrosis of this organ (Fig. 2) could well have interfered with some of its functions and thus accentuated the deficiency of factor $V$ in the plasma.

The exact cause of hepatic and cardiac necrosis in the present case is difficult to establish. Since blood was transfused 30 days before death, a pre-icteric stage of homologous serum hepatitis may be thought of as an aetiological factor. This would not explain the accompanying cardiac necrosis, and other causes should, therefore, be considered.

As far as we are aware, no proteolytic action other than that on blood-clotting factors has yet been ascribed to the fibrinolysin. However, its action on the heart and liver cells or the presence in plasma of another proteolytic agent affecting the cellular proteins of these organs cannot be entirely excluded. Beraldo (1950) and Lewis and Work (1957) described the formation in vitro of a bradykinin-like substance by the action of plasmin on plasma proteins, and it may be argued that the lesions in the heart and liver are probably due to the formation in vivo of this hypotensive substance. However, the therapeutic use of human plasmin in 42 cases of thromboembolic disease (Cliffton, 1958) was apparently free $\stackrel{\vec{\rho}}{\overrightarrow{0}}$ of serious hazards, pyrexia and urticarial reaction? being the only complications recorded. Furthermore, 흐 the patient showed no clinical signs of shock and no histological changes were seen in the kidneys, $\mathbb{\otimes}$ lungs, or adrenals to suggest the occurrence of this state.

Another possibility is that the hepatic and cardiac $\vec{\circ}$ lesions are produced by $\epsilon$-aminocaproic acid. $\overrightarrow{\vec{H}}$ Following the administration of $\epsilon$-aminocaproic $\stackrel{\omega}{\omega}$ acid the only side-effects recorded by Nilsson, Björkman, and Andersson (1961) were dizziness, nausea, and diarrhoea. No special post-mortem features were observed in three patients who received ${ }_{0}$ this compound (Nilsson, Sjoerdsma, and Walden- $\vec{\overrightarrow{ }}$ ström, 1960). Nevertheless, bearing in mind the potential toxicity of every new drug, it would be of ${ }_{c}^{-}$ interest to note carefully the histological findings in the liver and heart in future patients treated with this drug.

We wish to thank Dr. H. G. Mather, under whose careo this patient was, Dr. F. J. W. Lewis, Director of the Department, Dr. N. J. Brown, for reading the manu-D script, Mr. R. H. Poulding for preparing the photo-乏 micrographs, and the Showering Fund for defraying some of the expenses.

\section{REFERENCES}

Astrup, T. (1956). Lancet, 2, 565.

Beraldo, W. T. (1950). Amer. J. Physiol., 163, 283.

Cliffton, E. E. (1958). J. Amer. Geriat. Soc., 6, 118.

Cosgriff, S. W., and Leifer, E. (1952). J. Amer. med. Ass., 148, 462

Lewis, G. P., and Work, T. (1957). J. Physiol. (Lond.), 135, 7 P.

Nilsson, I. M., Björkman, S. E., and Andersson, L. (1961). Acta mect-o scand., 170, 487.

- Sjoerdsma, A., and Waldenström, J. (1960). Lancet, 1, 1322.

Owren, P. A. (1949). Scand. J. clin. Lab. Invest., 1, 131.

Sherry, S., Fletcher, A. P., and Alkjaersig, N. (1959). Physiol. Rev. ̊̊ 39, 343.

Stefanini, M. (1951). Lancet, 1, 606.

Tagnon, H. J., Schulman, P., Whitmore, W. F., and Kravitz, S. C을 (1952). J. clin. Invest., 31, 666. 